DOI 10.15826/qr.2018.1.281

УДК 94(470)"17"+94(4-011)"17"+929Петр(470)*I+327.82(09)

\author{
ПУТЕШЕСТВИЕ ВИЦЕ-КАНЦЛЕРА \\ П. П. ШАФИРОВА В ЗАПАДНУЮ ЕВРОПУ \\ $(1716-1717)^{*}$
}

Татьяна Базарова

Санкт-Петербургский институт истории РАН,

Санкт-Петербург, Россия

\title{
THE JOURNEY OF VICE-CHANCELLOR PYOTR SHAFIROV TO WESTERN EUROPE (1716-1717)
}

Tatiana Bazarova

St Petersburg Institute of History of the Russian Academy of Sciences,

St Petersburg, Russia

This article examines various aspects of the activity of Vice-chancellor Pyotr Pavlovich Shafirov (1673-1739) during the journey of Peter the Great to Western Europe between 1716 and 1717. At the beginning of his service, P. P. Shafirov had participated in the Great Embassy (1697-1698) as a translatorof Dutch and German: between 1716 and 1717, he accompanied Peter I during his journey to Western Europe as one of the heads of the Ambassadorial Prikaz (Posolsky Prikaz). Data about Shafirov's activity during the tsar's journey and the duties assigned to him can be found in published sources (for example, the field diaries and expense accounts of Peter I, letters and memoirs of foreign participants, etc.) and archival sources. The latter include not only the office materials of the Ambassadorial Prikaz (RGADA) but also letters the vice-chancellor exchanged with his wife, A. D. Menshikov, and F. M. Apraksin. An examination of correspondence shows that the vice-chancellor had to deviate from the tsar's route to carry out various assignments. During his trip abroad, Peter I concluded two treaties of alliance, those of Mecklenburg (1716) and Amsterdam (1717). Shafirov played one of the leading roles in the negotiations, drafting the texts of both agreements. After the failure of the allied assault on Skåne (1716), the vice-chancellor, along

* Citation: Bazarova, T. (2018). The Journey of Vice-Chancellor Pyotr Shafirov to Western Europe (1716-1717). In Quaestio Rossica, Vol. 6, № 1, p. 46-62. DOI 10.15826/ qr.2018.1.281.

Цитирование: Bazarova T. The Journey of Vice-Chancellor Pyotr Shafirov to Western Europe (1716-1717) // Quaestio Rossica. Vol. 6. 2018. № 1. P. 46-62. DOI 10.15826/ qr.2018.1.281 / Базарова Т. Путешествие вице-канцлера П. П. Шафирова в Западную Европу (1716-1717) // Quaestio Rossica. T. 6. 2018. № 1. C. 46-62. DOI 10.15826/qr.2018.1.281. 
with G. I. Golovkin, B. I. Kurakin, and P. A. Tolstoy, tried to prevent the disintegration of the Northern Union through diplomacy. In addition to solving diplomatic problems, Shafirov carried out other assignments from the tsar. The vice-chancellor bought useful objects and luxury items for the tsar and tsarina in Paris. He was responsible for hiring sailors for the Russian service in Amsterdam and Hamburg and sending Western European specialists to Russia in 1717. For this purpose, he was provided with considerable sums from the state treasury. A few years after the trip to Western Europe, Shafirov was suspected of embezzlement, which led to judicial investigations. In 1720, the Revision Collegium required the vice-chancellor to provide correspondence, bills, and receipts for the hiring of officers and sailors. The question of Sharfirov's embezzlement was still being raised by investigators as late as 1723 .

Keywords: $18^{\text {th }}$-century Russian history; Peter I; P. Shafirov; diplomatic relations; foreign specialists.

Исследуются различные аспекты деятельности вице-канцлера П. П. Шафирова (1673-1739) во время путешествия Петра I по Западной Европе в 1716-1717 гг. Если в начале своей службы Петр Шафиров участвовал в Великом посольстве 1697-1698 гг. в качестве переводчика, то в 1716-1717 гг. он сопровождал Петра I как один из руководителей Посольского приказа. Сведения о маршруте и обязанностях П. П. Шафирова можно обнаружить как в опубликованных, так и в архивных источниках. Последние включают не только делопроизводственные материалы Посольского приказа (РГАДА), но и переписку вице-канцлера с женой, А. Д. Меншиковым и Ф. М. Апраксиным. Переписка показывает, что вице-канцлеру для выполнения различных поручений приходилось отклоняться от маршрута государя. Во время заграничного путешествия Петр I заключил два союзных договора - Мекленбургский (1716) и Амстердамский (1717), в переговорах и разработке текстов которых одну из ведущих ролей сыграл П. П. Шафиров. После неудачи с организацией десанта союзников в Сконе (1716) вице-канцлер вместе с Г. И. Головкиным, Б. И. Куракиным и П. А. Толстым дипломатическим путем пытался предотвратить распад Северного союза. Помимо решения дипломатических задач, П. П. Шафиров покупал в Париже предметы обихода и роскоши для царя и царицы, отвечал за организацию приема на русскую службу матросов в Амстердаме и Гамбурге и занимался отправкой в Россию западноевропейских специалистов. Для этих целей ему были предоставлены значительные денежные средства из государственной казны. Спустя несколько лет после его возвращения возникло подозрение о нецелевой растрате им государственных средств, что привело к судебным расследованиям. В 1720 г. Ревизион-коллегия потребовала от вице-канцлера предоставить переписку, счета и расписки о найме офицеров и матросов за границей. Вопрос о растрате П. П. Шафировым казенных денег поднимался следователями и в 1723 г.

Ключевые слова: история России XVIII в.; Петр I; П. П. Шафиров; дипломатические отношения; иностранные специалисты. 
Первый в истории России вице-канцлер барон Петр Павлович Шафиров (1673-1739) начал свою многолетнюю службу с должности переводчика Посольского приказа (1691). В этом качестве он участвовал в Великом посольстве 1697-1698 гг. Во время этого путешествия в свите государя по Западной Европе П.П. Шафирову удалось сблизиться с Петром I, а также будущим главой Посольского приказа Ф.А. Головиным (1650?-1706), что положило начало его карьере дипломата и государственного деятеля.

Через 20 лет П.П. Шафиров вновь сопровождал Петра I в поездке по Западной Европе, но уже будучи одним из тех, кто определяли внешнюю политику России. К свободному владению голландским и немецким языками, знанию латыни он добавил разговорный итальянский, который выучил во время пребывания в качестве посла в Османской империи ${ }^{1}$. Однако основной задачей вице-канцлера во время второго большого заграничного путешествия Петра I был уже не перевод, а ведение переговоров с иностранными правительствами.

Поездка царя по Западной Европе 1716-1717 гг. была насыщена политическими событиями, встречами с иностранными монархами и их представителями (в ряде случаев заканчивавшимися подписанием соглашений и деклараций). Как правило, предварительную работу (не попадавшую на страницы договоров, указов и походных журналов государя) по согласованию протокола встречи, основных пунктов обсуждаемых документов и т.п. проделывали сопровождавшие Петра I дипломаты. В распоряжении царя, помимо П. П. Шафирова, находились и другие русские дипломаты. Государя сопровождали канцлер Г.И. Головкин и опытнейший политик П.А. Толстой. В середине 1710-х гг. Россия имела дипломатических представителей различного ранга практически во всех влиятельных государствах Европы, которые при необходимости присоединялись к свите государя. Во время путешествия по Голландии и Франции в свите Петра I находился полномочный министр в Гааге Б. И. Куракин $(1676-1727)^{2}$.

Участие в поездке опытных дипломатов давало возможность оперативно решать сразу несколько политических задач. П.П. Шафиров, Г.И. Головкин, П.А. Толстой и Б.И. Куракин не всегда оставались в царской свите и, выполняя поручения Петра I, отклонялись от основного маршрута ${ }^{3}$ Им нередко приходилось объединять усилия во время

${ }^{1}$ После заключения Прутского мира (12 июля 1711 г.) П. П. Шафиров и М. Б. Шереметев должны были оставаться в Османской империи в качестве полномочных министров (a, по сути, заложников) до выполнения Петром І взятых на себя обязательств. 13 августа 1712 г. им доставили грамоты о ранге чрезвычайных и полномочных послов. Османскую империю послам удалось покинуть только осенью 1714 г.

${ }^{2}$ По мнению Э. Вагеманса, второе путешествие Петра I в Голландию было целиком организовано Б. И. Куракиным [Вагеманс, с. 34].

3 Так, 18 мая 1716 г. (по ст. ст.) П. А. Толстой написал из Шверина Ф. М. Апраксину, что после отъезда царя он остался в столице Мекленбурга «при государыне царице и для окончания здешних дел». Также он сообщил генерал-адмиралу: «министры, государь, царского величества от иностранных дворов многие здесь при дворе его величества обретаются, а имянно князь Куракин, князь Долгорукой, граф Головкин, барон Шлениц и резидент Беткер, и когда паки по своим местам будут роспущены, о том еще неведомо» [РГАВМФ. Ф. 233. Оп. 1. Д. 129. Л. 63]. 
переговоров с иностранными министрами и заключения международных договоров, хотя известно, что дипломаты не питали друг к другу симпатий и давно соперничали между собой. Взаимная неприязнь приводила к конфликтам даже во время заграничного путешествия ${ }^{4}$.

Для изучения обязанностей П.П. Шафирова необходимо уточнить маршрут его поездки. Отдельные факты можно обнаружить как в опубликованных (письма царя и других участников событий, записки и мемуары иностранцев и пр.), так и в архивных источниках (делопроизводственные документы Посольского приказа и материалы следственных дел, переписка вице-канцлера с женой А. С. Копьевой, А. Д. Меншиковым, Ф.М. Апраксиным и пр. $\left.{ }^{5}\right)$.

\section{Европейский маршрут вице-канцлера}

Когда 27 января 1716 г. Петр I покинул Санкт-Петербург, направляясь через Прибалтику в Гданьск (где уже располагалась армия Б.П. Шереметева), вице-канцлера в свите государя не было. Только 14 февраля, в день своего отъезда из Либавы, царь отправил П. П. Шафирову распоряжение срочно прибыть к нему («а особливо, что король полской хочет быть для свидания, сам знаешь, что много всячины будет») [Архив СПбИИ РАН. Колл. 270. Оп. 1. Д. 81. Л. 206]'. Однако надо полагать, что вице-канцлер выехал из Санкт-Петербурга за несколько дней до царского указа. 15 февраля из Риги П. П. Шафиров сообщил Ф.М. Апраксину: «Я приехал сюда вчера и еду сегодня паки догонять его величество, а где, полутче не могу знать» [РГАВМФ. Ф. 233. Оп. 1. Д. 129. Л. 27]. 9 марта вице-канцлер уже отправлял письма из Гданьска [РГАДА. Ф. 160. Оп. 1. 1716 г. Д. 5. Л. 25 об.].

В Гданьске П. П. Шафиров вел переговоры с представителями двух иностранных держав. В марте 1716 г. Петр I стал посредником в деле примирения Августа II и Тарногрудской конфедерации, образованной в 1715 г. с целью борьбы с саксонским влиянием и низложения короля. В начавшихся в Гданьске совещаниях вместе с царем участвовали Г. И. Головкин, П. П. Шафиров и П. А. Толстой. Затем переговоры перенесли в Яро́слав, куда по указу царя отправился чрезвычайный посол в Польше Г. Ф. Долгорукий.

${ }^{4}$ С. Л. Владиславич-Рагузинский, по пути из Санкт-Петербурга в Венецию посетивший Петра I в Пирмонте (июль 1716), отметил: «Между господ министры Посолской канцелярии есть маленкая контра. Една партия господ двух Петр (Петра Шафирова и Петра Толстого. - Т. Б.), а другая господина графа (Г.И. Головкина. - Т. Б.). Бог Вышный да пошлет между всих мир, любовь и благодеяние, да пересекутся сори и ненависти» [РГАВМФ. Ф. 233. Оп. 1. Д. 126. Л. 63].

${ }^{5}$ Недавно опубликованные письма П.П. Шафирова, имеющие отношение к заграничному путешествию 1716-1717 гг., сохранились до нашего времени преимущественно в черновиках и копиях. См.: [Редин, Серов].

${ }^{6} 14$ февраля в Либаве граф Дунин передал Петру I грамоту Августа II о выводе русских войск из Польши и Курляндии. В письме польского короля государю содержалась просьба о личной встрече во время проезда через Польшу. 4 марта Петр I предложил Августу II встретиться в Гданьске [РГАВМФ. Ф. 233. Д. 129. Л. 53 об.-54; Бантыш-Каменский, ч. 3, с. 213]. 
Одновременно проходили встречи с дипломатами герцога Мекленбург-Шверинского Карла-Леопольда. П.П. Шафиров еще в СанктПетербурге занимался согласованием условий договора о супружестве герцога и племянницы государя царевны Екатерины Иоанновны. Брачный контракт подписали 22 января 1716 г., за несколько дней до отъезда государя из столицы. 27 марта в Гданьске договор ратифицировали, и 8 апреля7 ${ }^{7}$ состоялась свадьба Екатерины Иоанновны и герцога. На церемонии бракосочетания присутствовал не только Петр I, но и польский король Август $\mathrm{II}^{8}$.

В течение нескольких месяцев до и после свадьбы (весной-летом 1716 г.) П. П. Шафиров вместе с канцлером Г.И. Головкиным вел непростые переговоры с гофмаршалом мекленбургского герцога Карла Леопольда бароном Эйхгольцем, согласовывая условия союзного договора (передача герцогу Висмара, размещение в герцогстве русского корпуса, решение проблем с мекленбургским дворянством и проч.) ${ }^{9}$. Эти встречи продолжались и после отъезда дипломатов из Гданьска. «Мекленбургский вопрос», связанный с пребыванием русских войск на территории герцогства, красной нитью пройдет через всю политическую историю заграничного путешествия Петра I и значительно осложнит отношения России с европейскими государствами, особенно с Данией, Империей, Ганновером и Великобританией [Бобылев, с. 96-97; Молчанов, с. 334-339].

Гданьск П.П. Шафиров покинул, надо полагать, в составе свиты государя 11 мая 1716 г. Вместе с Петром I он посетил Шверин, Гамбург и Альтену, где 6 июня состоялись переговоры с датским королем об организации десанта в Сконе [Гистория, с. 446]. В июне 1716 г. Б. И. Куракин написал Ф. М. Апраксину из Ганновера: «И по заключении того письменнаго согласия царское величество в Альтоне, обедав у короля датскаго, изволил идти в Пирмонд, взяв с собою токмо великого канцлера и подканцлера» [Материалы, ч. 4, с. 103-104] ${ }^{10}$.

Государь приехал в Пирмонт ${ }^{11}$ (где «начал воду пить и все при нем будучие») 7 июня 1716 г. [Походный журнал 1716 г., с. 25, 78]. После курса лечения П.П. Шафиров в свите царя отправился через Шверин и Росток в Копенгаген. В датской столице Петр I намеревался сосредоточить эскадры парусного и галерного флотов, доставить русские войска из Мекленбурга и вместе с датскими и британскими военно-морскими силами

${ }^{7}$ Далее все даты, касающиеся заграничного путешествия, приводятся по новому стилю (кроме особо оговоренных случаев).

8 Участвовавший в торжестве П.П. Шафиров описал церемонию в письме А. Д. Меншикову. Черновик см.: [РГАДА. Ф. 9. ОП. 5. Д. 1. Ч. 4 Л. 482-483].

9 П. П. Гец на основании воспоминаний Эйхгольца предположил, что Карл Леопольд «...умел склонить на свою сторону Шафирова, который слепо вошел во все намерения герцога» [Гец, с. 17].

${ }^{10}$ Остальные дипломаты разъехались выполнять другие поручения государя: Б. И. Куракин отправился в Ганновер, а затем в Гаагу «для окончания известной негоциации с английским двором», П.А. Толстой и Г. Ф. Долгорукий поехали в Мекленбург для сбора продовольствия и найма судов для перевозки кавалерии [Материалы, ч. 4, с. 103-104].

${ }^{11}$ Бад-Пирмонт - водный курорт в Нижней Саксонии. 
высадить десант в Сконе, чтобы нанести сильный удар Швеции и принудить Карла XII к миру. Тогда бы и пригодились навыки П. П. Шафирова по ведению мирных переговоров. Однако военные действия сделались невозможными из-за разлада между союзниками (которые усугубляло и «мекленбургское дело»). Вместо конференций о мире со шведами вице-канцлер участвовал в переговорах государя с датским королем Фредериком IV об условиях переноса десанта в Сконе на следующую кампанию12. В ноябре 1716 г. П. П. Шафиров сообщил А. Д. Меншикову, что перед самым отъездом из Копенгагена Петр I «довольно еще изволил чрез меня наодине говорить с королем дацким и склонять его к действам предбудущей кампании в Шонах» [Редин, Серов, с. 481].

23-28 ноября 1716 г. П.П. Шафиров участвовал в переговорах Петра I с прусским королем Фридрихом Вильгельмом I (уже связанным соглашением с Францией) в Гавельсберге (Хафельберге), где были подписаны две декларации (о подтверждении союза и взаимных гарантиях отвоеванных у шведов территорий, также прусский король пообещал возобновить договор о дружбе с Мекленбургом) и обсуждался вопрос о русско-прусско-французском союзе [Мартенс, с. 154-157; Молчанов, с. 344; Фейгина, с. 106-108].

18 декабря - на день позже Петра I - П.П. Шафиров вместе с Г.И. Головкиным, П.А. Толстым и Б.И. Куракиным прибыл в Амстердам [Гистория, с. 611]. В голландской столице вице-канцлер провел всю зиму. 27 декабря (7 января) царь «заболел лихораткой» и был вынужден длительное время оставаться в постели, «ибо оная жестокая лихоратка умножилась с огневицею и продолжалась февраля до 10 числа» [Гистория, с. 611]. Болезнь протекала очень тяжело и с осложнениями. Приближенные серьезно опасались за жизнь Петра I, поэтому старались держать информацию о его здоровье в тайне. Так, П.П. Шафиров сообщил о болезни царя А. Д. Меншикову только после того, как кризис миновал [Редин, Серов, с. 479-480].

После выздоровления государя возобновилась его дипломатическая активность. Из Амстердама был отправлен мемориал английскому королю Георгу Iㄹ. 15 марта 1717 г. государь ответил на послание

${ }^{12} \mathrm{~K}$ началу 1717 г. относится собственноручная записка Петра I о совместных действиях с датчанами и англичанами в предстоящую кампанию. Надо полагать, она предназначалась послу в Дании В. Л. Долгорукому. Под текстом записки П. П. Шафиров приписал, что если Великобритания не согласится на предложения царя, то Россия будет соблюдать условия конвенции, заключенной в Альтене. См.: [Материалы, ч. 4, с. 129-130]. Провал совместной операции против шведов свидетельствовал о фактическом распаде Северного союза. В 1717 г. десант также не состоялся.

${ }^{13}$ В начале 1717 г. в Англии раскрыли один из заговоров яковитов (сторонников Якова III Стюарта), в организации которого принимали участие шведы. 9 февраля 1717 г. в Лондоне арестовали шведского посла К. Юлленборга (в течение нескольких месяцев он содержался под стражей и был выслан в Швецию в августе 1717 г.). Среди конфискованных бумаг посла обнаружили письма, в которых речь шла о Петре I и лейб-медике Р. Арескине, что дало английскому правительству повод обвинить Россию в причастности к заговору. Официальный ответ Петра I, в котором отрицалось участие русского двора в замыслах шведов, был вручен секретарем русского посольства в Лондоне Ф. П. Веселовским в марте 1717 г. [Бантыш-Каменский, ч. 1, с. 131; Стерликова, с. 66]. 
императора Карла VI (от 2 января) о жалобах мекленбуржцев на причиняемые им русскими войсками обиды [Бантыш-Каменский, ч. 1, c. 47]. Надо полагать, что в создании этих документов принимал участие П. П. Шафиров.

19 марта Петр I прибыл в Гаагу, в сопровождавший государя свите был и П. П. Шафиров. В Гааге царь остановился в резиденции Б. И. Куракина и лично приступил к русско-французскому политическому диалогу. 21 марта он дал аудиенцию послу Франции П.А. де Шатонёфу (который незадолго до этого вместе с аббатом Дюбуа заключил в Гааге тройственный союз Франции, Англии и Голландии) [Фейгина, с. 120; Мезин, с. 54-55; Вагеманс, с. 120]. Поиск точек соприкосновения русских и французских интересов протекал непросто. Россию на переговорах представлял свободно владевший французским языком Б.И. Куракин (вице-канцлер, по-видимому, оставался в тени). Вначале министры рассматривали возможность торгового соглашения, потом этот вопрос отошел на второй план. Царь готов был принять французское посредничество на мирных переговорах и заключить союзный договор с королем. Французская сторона отказывалась гарантировать России сохранение завоеваний в Прибалтике. Путем уступок дипломатам удалось согласовать условия русско-прусскофранцузского альянса, которые были отправлены французскому правительству [Мезин, с. 56; Фейгина, с. 122-127; Молчанов, с. 345-347].

30 марта царь с царицей выехали из Гааги в Роттердам, а П.П. Шафиров в тот же день вернулся в Амстердам, чтобы выполнить государев указ - организовать прием голландских матросов на русскую службу. По словам французского посла в Голландии маркиза Пьера Антуана де Шатонёфа, вице-канцлер «всегда был против поездки царя во Францию и все еще намерен предпринять последнюю попытку его отговорить», поскольку считал, что договор не принесет России политических дивидендов (цит. по: [Вагеманс, с. 98]).

С.А. Мезин полагает, что царь решил посетить Францию во время пребывания в Гааге с целью ускорить переговоры [Мезин, c. 56]. Уже 29 марта Б.И. Куракин сообщил об этом французским дипломатам, добавив, что государь намерен держать свое путешествие в тайне. На следующий день П. А. де Шатонёф написал в Париж о возможном маршруте царя: Зеландия, Остенде, Ньюпорт, Дюнкерк, Мардик и Кале [Там же, с. 57]. По мнению С. А. Мезина, П.П. Шафирову о планах царя посетить Францию сообщили не сразу [Там же]. Российский торговый агент в Амстердаме Йоханнес ван ден Бюрг (Фонденбург) ${ }^{14}$ доставил вице-канцлеру письмо от сопровождавшего царя П.А. Толстого (от 10 апреля с яхты близ Флисинга) с сообщением: «О вашем прибытии к нам не упоминается, понеже дел никаких нет» [Походная канцелярия, с. 480-481].

14 Йоханес (Яган) ван ден Бюрг (Фандербурх, Фондербург) (1663-1731) - российский агент (с 1706 или 1707 г.), коммерц-советник в Амстердаме (после 1716 г.). 
И только через три дня, 13 апреля 1717 г., Петр I вызвал П.П. Шафирова к себе: «Приезжайте во Фляндрию, ибо чаю праздник тут взять, намерение мое есть во Францию...» [Архив СПбИИ РАН. Колл. 270. Оп. 1. Д. 84. Л. 324-325]. Получив царский указ, вице-канцлер немедленно тронулся в путь. 15 апреля он сообщил Ф.М. Апраксину: «...я сего дня отъезжаю за его величеством по указу в Брабандию» [Редин, Серов, с. 494]. Однако присоединиться к многочисленной свите, сопровождавшей царя на пути в Париж ${ }^{15}$, П. П. Шафирову удалось уже на французской земле.

21 апреля королевский камер-юнкер де Либуа после встречи с государем в Дюнкерке сообщил в Париж: «Он проведет здесь по крайней мере четыре дня, так как намеревается лечиться и ждать приезда своего вице-канцлера» [Документы, относящиеся до пребывания царя, с. 140]. Так и не дождавшись П. П. Шафирова, Петр I продолжил свой путь и прибыл в Кале 25 апреля. Оттуда через два дня де Либуа сообщил в Париж о приезде вице-канцлера [Там же, с. 163-164, 166] ${ }^{16}$. По прибытии П.П. Шафиров занял в свите государя важное место, что сразу отметил де Либуа, который сообщил регенту Филиппу II Орлеанскому: «Приезд Шафирова значительно ослабил влияние князя Куракина» [Там же, с. 170]. Вместе с царем П. П. Шафиров приехал в Париж и остановился на отдельной квартире на Гранд Комдежезу [Сборник выписок, с. 70], очевидно, находившейся близ отеля Ледигьер, где расположился Петр I.

\section{Деятельность вице-канцлера во Франции и Голландии}

Дальнейшие русско-французские переговоры проходили уже при активном участии П.П. Шафирова ${ }^{17}$. Вице-канцлер умело оттеснил Б. И. Куракина на второй план и сам через переводчиков общался с королевскими министрами ${ }^{18}$. С 18 по 20 мая 1717 г. прошло три совещания русских и французских дипломатов. 27 мая к ним присоединился представитель Пруссии барон Ф.Э. Книпгаузен, на-

${ }^{15}$ С. А. Мезин отметил, что в Кале государя сопровождало около 80 человек [Мезин, с. 93].

${ }^{16} 16$ (27) апреля 1717 г. П. П. Шафиров отправил из Кале письмо Г. И. Головкину в Амстердам [РГАДА. Ф. 160. Оп. 1.1717 г. Д. 14. Л. 10].

17 В Париже с русской стороны, помимо П.П. Шафирова, в переговорах участвовали Б.И. Куракин, П. А. Толстой, В.В. Долгорукий. Существенную помощь петровским дипломатам оказывал советник канцелярии А. И. Остерман. Когда летом 1717 г. П. П. Шафиров покидал Париж, чтобы последовать за государем в Спа, он был вынужден оставить во французской столице заболевшего А.И. Остермана. Вицеканцлер написал Г.И. Головкину: «и тако без него в делех не бес труда мне будет, ежели случитца» [РГАДА. Ф. 160. Оп. 1. 1717 г. Д. 14. Л. 53 об.].

${ }^{18}$ Для работы над основными положениями союзного соглашения П. П. Шафирову понадобились копии всех имевшихся в походной канцелярии международных договоров. 15 мая (по ст. ст.) он написал Г. И. Головкину в Амстердам, и 24 мая 1717 г. эти документы были уже доставлены в Париж [РГАДА. Ф. 160. Оп. 1. 1717 г. Д. 14. Л. 23-26 об., 40 об.]. 
кануне прибывший из Берлина [Документы, относящиеся до пребывания царя Петра I, с. 196-210; Мезин, с. 117-121]. Последнее совещание состоялось 12 июня, а 20 июня царь покинул французскую столицу. Перед своим отъездом он подписал полномочную грамоту на дальнейшее ведение переговоров и заключение союзного договора П.П. Шафирову, П.А. Толстому и В.В. Долгорукому. После отъезда царя в Спа П.П. Шафиров и П. А. Толстой на несколько дней задержались во французской столице «для окончания известного дела, которое, почитай, уже к сходству пришло...» [РГАДА. Ф. 160. Оп. 1. 1717 г. Д. 14. Л. 43-44] ${ }^{19}$. В Париже дипломаты согласовали основные положения союзного договора, однако прусский представитель не имел полномочий его подписывать. Поэтому переговоры перенесли в Амстердам, где 15 августа 1717 г. был заключен союз между Россией, Францией и Пруссией ${ }^{20}$. С русской стороны его подписали Г.И. Головкин, П.П. Шафиров и Б.И. Куракин ${ }^{21}$ Амстердамский договор, наряду с Мекленбургским союзным договором, стал важным итогом деятельности П. П. Шафирова как дипломата и политика во время заграничного путешествия.

Помимо этого, П. П. Шафиров налаживал деловые контакты, вместе с царем и его придворными осматривал крепостные укрепления и городские достопримечательности, посещал театры, соборы, загородные резиденции, сады и парки, библиотеки и мануфактуры. Не забывал вице-канцлер и о своем новом каменном дворце на Городском острове в Санкт-Петербурге. В Амстердаме по его распоряжению закупили цемент («которую употребляют в погребах от воды»), а также шпалеры для «обития в полатах петербурских». Этот груз отправили на корабле в Архангельск, и 28 июля 1716 г. вице-канцлер написал письмо архангелогородскому вице-губернатору П. Е. Лодыженскому с просьбой позаботиться о его охране и доставке к месту назначения [РГАДА. Ф. 9. ОП. 5. Д. 1. Ч. 4. Л. 559].

В заграничной поездке вице-канцлер расходовал не только личные, но государственные денежные средства. Так, перед прибытием в Париж П.П. Шафиров получил некую сумму, предназначавшуюся на приобретение различных вещей для царя и царицы. В расходных книгах кабинетных денег сохранились записи о выдаче П.П. Шафирову «за уборы», купленные «про государыню царицу 3000 ливров», а также за

19 П. А. Толстой сообщил А.Д. Меншикову о своем прибытии в Спа вместе с П.П. Шафировым 19 июня 1717 г. [Материалы, ч. 4, с. 137-138]. На этом бельгийском курорте П.П. Шафиров и П.А. Толстой согласовывали с Эйхгольцем вопрос о числе полков, которые по просьбе Карла Леопольда должны были остаться в Мекленбурге после вывода оттуда русской армии [Гец, с. 19].

20 Текст договора см.: [Мартенс, с. 157-168].

${ }^{21}$ П. А. Толстой в дальнейших переговорах не участвовал. 21 июля он был отправлен из Спа в Вену «для известного дела» [РГАДА. Ф. 160. Оп. 1. 1717 г. Д. 14. Л. 56]. Перед отъездом Петр Андреевич получил от государя инструкцию о доставке царевича Алексея Петровича обратно в Россию [Архив СПбИИ РАН. Колл. 270. Оп. 1. Д. 85. Л. 16]. 
шарф и ленты для царицы «да за платье государю царевичу, всего 800 ливров» [Сборник выписок, с. 69]. 14 июня 1717 г. П.П. Шафирову наличными и векселями выделили «на отправление из Парижа в Питербурх мастеровых людей 40000 ливров» [Там же, с. 66-67].

\section{Расследование расходов казны на найм морских служителей}

Через несколько лет после возвращения на родину П.П. Шафирову пришлось объяснять следователям, как он тратил государевы деньги в 1716-1717 гг. Материалы затянувшегося на несколько лет расследования о расходах казны на найм матросов на русскую службу позволяют глубже изучить одну из малоизвестных страниц заграничного путешествия [РГАДА. Ф. 50. Оп. 1. 1717 г. Д. 23].

В 1720 г. Коллегия иностранных дел запросила у П. П. Шафирова царский указ, по которому он вел прием на службу зарубежных специалистов. Петр Павлович предъявил указ, датированный 15 марта 1717 г. (по ст. ст.), где государь велел ему принять на российскую службу морских офицеров и две-три тысячи матросов. «И вручена та коммисия... Петру Павловичю Шафирову, и при нем велено быть для вспоможения канцелярии советнику Андрею Остерману да для переводу и писма переводчику Петру Ларионову». На найм специалистов выделялось 30 тысяч рублей червонными. На эту сумму П. П. Шафиров принял у купцов в Амстердаме векселя, которые были присланы В.В. Долгоруким из России для выплаты жалования лейб-гвардии Преображенскому полку 22 .

В конце марта П.П. Шафиров вместе со своими служителями прибыл из Гааги в Амстердам ${ }^{23}$, где заключил договор с местными купцами Абрабанелями (Исааком Абрабанелом (Абарбанелем) с сыновьями). Купцы получили инструкцию принимать на русскую службу только опытных матросов, «которые уже на море доволно служили и в том добрые свидетелства подать могут». Деньги «тем наемным людям» позволялось выплачивать только после погрузки на корабль или после предоставления «добрых порук». Всем принятым на русскую службу разрешалось выдать в Амстердаме двухмесячное жалование по 12 гульденов на месяц (последующие

22 Жалование гвардейцам заплатили из «кабинетной казны наличною манетою, в Мекленбургии обретающейся, потому что и гвардия обретается тамо ж». Под копией указа - приписка: «Таков великого государя указ за подписанием государственного подканцлера тайного советника барона Петра Павловича Шафирова» [РГАДА. Ф. 50. Оп. 1. 1717 г. Д. 23. Л. 2-2 об.]. Надо полагать, что оригинал указа не сохранился. Не был он известен и Комиссии по изданию писем и бумаг Петра Великого. Неизданные тома копий писем царя за 1716 и 1717 г. хранятся в Архиве СПбИИ РАН в коллекции 270 («Коллекция Комиссии по изданию писем и бумаг Петра Великого»).

${ }^{23}$ В 1720 г. П. П. Шафиров показал, что выехал в Амстердам из Гааги 19 марта 1717 г. (по ст. ст.) [РГАДА. Ф. 50. Оп. 1. 1717 г. Д. 23. Л. 3]. Однако среди делопроизводственных материалов Посольского приказа сохранилось письмо вице-канцлера, отправленное 20 марта из Гааги. Впрочем, 22 марта он (как и канцлер Г.И. Головкин) уже находился в Амстердаме [РГАДА. Ф. 160. Оп. 1. 1717 г. Д. 1. Л. 47 об., 48]. 
выплаты предполагалось делать в России в рублях по вексельному курсу) [РГАДА. Ф. 50. Оп. 1. 1717 г. Д. 23. Л. 3-4 об.]. Предназначенные на найм матросов 30 тысяч червонных векселями и наличными П.П. Шафиров передал агенту ван ден Бюргу с распоряжением «из тех денег по требованию вышеписанных купцов на наем матрозов давать по некоторому числу с роспискою» [Там же. Л. 5-5 об.]. Из Амстердама вице-канцлер сообщил Ф. М. Апраксину, что на русскую службу будет принято до полутора тысяч матросов (первоначально запланированное число уменьшилось в два раза), а также пять-восемь «старых и искусных поручиков в капитаны», штурманов и боцманов. Нанятых в Амстердаме матросов и офицеров планировали на русских кораблях отправлять в Ревель [Материалы, ч. 3, с. 149; Редин, Серов, с. 494].

Как отмечалось выше, 15 апреля 1717 г. П.П. Шафиров по указу царя выехал из Амстердама и присоединился к нему во время поездки в Париж. Во Франции П.П. Шафиров и ван ден Бюрг получили просьбу Абрабонелей о расторжении соглашения, поскольку не могли нанять в Голландии требуемое число специалистов. Купцы пояснили, что на лов китов в Гренландии уже снаряжено около 200 кораблей с командами из 40-45 матросов («...и каждому матрозу по осмнатцати гулденов на месяц тою компаниею найму дают и еще сверх того по три гулдена с каждого кита, которого поймают»), поэтому свободных «морских служителей» практически не осталось [РГАДА. Ф. 50. Оп. 1. 1717 г. Д. 23. Л. 5 об.-6].

После доклада П. П. Шафирова Петр І указал «вручить ту комисию советнику комерции и агенту своему в Амстердаме обретающемуся Фан ден бургу» [Там же. Л. 6]. Однако и опытный торговый агент ван ден Бюрг, который в течение нескольких лет отвечал за прием на царскую службу голландских офицеров, матросов и мастеровых [Вагеманс, с. 42], по тем же причинам не смог найти полторы тысячи «морских служителей». 8 июля 1717 г. (по ст. ст.) уже во время пребывания в Спа государь поручил русскому резиденту в Гамбурге И. Ф. Бетигеру нанять в Гамбурге и Любеке тысячу матросов и отправить их в Ревель [РГАДА. Ф. 50. ОП. 1. 1717 г. Д. 23. Л. 6 об.] ${ }^{24}$. Ван ден Бюрга обязали передать резиденту часть предназначенной на найм специалистов суммы из 30 тысяч червонных (которые он уже успел обменять на 159 тысяч гульденов) [Там же. Л. 7-7 об.].

Итак, в 1717 г. «морских служителей» нанимали два агента - ван ден Бюрг и И.Ф. Бетигер, которые в своих тратах должны были отчитываться перед П. П. Шафировым. В РГАВМФ сохранились переводы писем ван ден Бюрга Ф.М. Апраксину, в которых тот подробно описывает все сложности, с которыми ему пришлось столкнуться, выполняя царский указ. 27 июня 1717 г. ван ден Бюрг писал Ф. М. Апраксину, что ему «с немалым трудом» удалось нанять 150 матросов,

\footnotetext{
${ }^{24}$ Бетигер (Бетхер) Иоганн Фридрих - русский резидент в Гамбурге в 1712-1718 гг.
} 
и пообещал прислать список [РГАВМФ. Ф. 233. Оп. 1. Д. 113. Л. 51]. Группы по нескольку десятков человек в сопровождении солдат он отправлял на шмаках в Гамбург к И.Ф. Бетигеру [Там же. Л. 72]. 19 октября ван ден Бюрг доложил Ф. М. Апраксину, что «ныне матрозов принято 340 человек» [Там же. Л. 85 об.]. Он жаловался, что на русскую службу намериваются поступить в основном малоопытные матросы. Определенную надежду Ван ден Бюрг возлагал на наступление холодов: «разве зимою которые найдутца, понеже зимою многим бывает отпуск». Несмотря на то, что от пожелавших ехать в Россию требовали «аттестацию принесть, с кем на карабле служили» [Там же. Л. 85-85 об.], на царской службе оказались люди, мало сведущие в морском деле.

В конце осени 1717 г. Ф.М. Апраксин получил донос из Копенгагена. Ван ден Бюрга и И.Ф. Бетигера обвиняли в том, что они принимают в матросы «из мастеровых людей, которые отнють морскому необучены и морскому делу неискусны, и дают оклад немалой по 5 рублев человеку на месяц». При этом резидент и агент «корыстаютца сами по служителех, в чем его царскому величеству не без убытку» [РГАВМФ. Ф. 233. Оп. 1. Д. 143. Л. 92-92 об.]. К доносу прилагался список из 45 имен сапожников, башмачников, садовников, ткачей и прочих мастеровых, принятых матросами на русскую службу [Там же. Л. 94-95]. Согласно ведомости контр-адмирала Дж. Паддона, освидетельствовавшего принятых в Гамбурге И.Ф. Бетигером служителей, из 104 человек 40 по разным причинам оказались непригодны к морской службе. К тому же 14 «матросов» вообще «на море не бывали» [Материалы, ч. 3, с. 171].

После возвращения в Санкт-Петербург П.П. Шафиров продолжал переписываться с агентом и резидентом. 13 декабря 1717 г. он передал И.Ф. Бетигеру указ государя, чтоб «вы по содержанию такой набор весьма оставили и более никаких людей не принимали» [Там же, с. 164]. «Морских служителей», с которыми договоры уже были подписаны, следовало водой или сушей отправлять в Шверин ${ }^{25}$. От И.Ф. Бетигера также потребовали немедленно прислать список людей и счета [Там же].

Несмотря на сложности, Й. ван ден Бюргу и И. Ф. Бетигеру в 1717 и 1718 г. удалось отправить в Россию несколько сотен моряков. Однако когда Адмиралтейство решило уточнить, кого именно и на каких условиях приняли на службу, оно столкнулось с проблемами. К тому же не все указанные в списках моряки прибыли в Россию. В ноябре 1718 г. Адмиралтейство направило в Коллегию иностранных дел «ведение» о принятых на службу «морских служителях». Копию послали в Гамбург резиденту И.Ф. Бетигеру. Резидент ответил, что некоторые имена «не сходны»: были те, кого он не нанимал, а тех, кого

${ }^{25}$ Из Шверина в Ригу людей отправлял М.А. Матюшкин [Осмннадцатый век, с. 39; Рескрипты и указы, с. 437; Материалы, ч. 3, с. 161, 165]. 
нанимал, не было. Он также прислал список сомнительных 42 имен [РГАДА. Ф. 50. ОП. 1. 1717 г. Д. 23. Л. 181-182]. После этого и обратились к П.П. Шафирову. 20 июля 1720 г. дело о «принятии на российский флот морских афицеров и матрозов в Галандии и Гамбурке» доставили из дома вице-канцлера в приказную экспедицию Коллегии иностранных дел. В сентябре 1720 г. от П.П. Шафирова и его зарубежных корреспондентов потребовали предоставить счета и квитанции о найме офицеров и матросов в Ревизион-коллегию ${ }^{26}$.

После перевода на русский язык счетов и отчетов выяснилось, что часть суммы агент и резидент взяли в счет не выплаченного им годового денежного жалования, а ряд расходов на продовольствие, дрова, уголь не удалось подтвердить документами. Деньги тратили на лечение и погребение, награду за возврат бежавших матросов и пр. В присланной И.Ф. Бетигером записке о не подтвержденных счетами тратах упоминается и способ «агитации» матросов поступать на русскую службу: «Также давал я по все время вербования квартирмастерам на пропой, чтоб они могли для прииску людей во всякие питейные домы ходить по вся недели по 9 марков с 1-го сентября 1717 до 19-го февраля 1718» [Там же. Л. 146 об.]. Неудивительно, что протрезвевшие люди бунтовали, бежали, прыгая за борт в холодную воду [Там же. Л. 147].

В течение нескольких лет служители Ревизион-коллегии старались разобраться, на что были потрачены государевы деньги. Еще 25 июля 1723 г. у агента и резидента требовали предоставить отчет и указать, сколько денег у них осталось.

\section{Расследование парижских трат П.П. Шафирова}

Во французской столице вице-канцлер потратил казенные деньги не только на государевы нужды. В конце 1710-х гг. дело о пропаже 5389 ливров приняла к рассмотрению Юстиц-коллегия. Тогда вицеканцлеру удалось оправдаться и обвинить в хищении канцеляриста Федора Протопопова [Серов, 2008, с. 99]. 17 января 1723 г., Петр I распорядился создать временную канцелярию, которой поручили расследовать хищение П.П. Шафировым денежных средств в 17161717 гг. [Там же, с. 103, 130]. Вышний суд поднял вопрос о нецелевых тратах казенных средств. Согласно донесению Ф. Протопопова, вице-канцлер израсходованные в парижском походе на личные нужды деньги записывал как «государевы» расходы. На допросе вице-канцлер сообщил, что «от Кале до Парижа в пути в разных местах при смотре костелов, манифактуров, садов и иных достойных смотрению мест в Париже», в операх и комедиях, в Версале и других загородных резиденциях, а также в Спа «доктурам и аптекарю, которые

\footnotetext{
${ }^{26} 8$ октября 1720 г. по указу Петра I материалы дела и все иностранные счета были переданы «для подлинного счету» в Ревизион-коллегию [РГАДА. Ф. 50. Оп. 1. 1717 г. Д. 23. Л. 210].
} 
всегда при дворе были, в презент и за лекарства, и капуцыннам на милостину» им было роздано «черванными 63, ефимков 36, ливеров 2479» [РГАДА. Ф. 248. Кн. 300. Л. 279]. При этом, по его показаниям, он не имел ни письменного, ни устного указа Петра I на подобную трату, а «роздавал по тамошнему обыкновению и с примеру прежних таких же случаев и походов, как и другие министры держали за честь его величества свои собственныя денги (курсив мой. - Т. Б.)» [Там же. Л. 281].

На обвинение в покупке на государевы деньги «почтовой шезы» ${ }^{27}$ за 350 ливров П. П. Шафиров ответил, что не вернул их в казну, «для того что в том походе все были на иждивении его императорского величества» [РГАДА. Ф. 248. Кн. 300. Л. 280]. Однако все-таки был вынужден признать, что для публичной церемонии, когда французский король и Петр I обменивались визитами ${ }^{28}$, заплатил из государевых денег за «зделанное платье» ему, Шафирову, «1564 ливера 9 штиверов» без разрешения государя. Но пояснил, что «делал в надежде на милость государеву, понеже министром которые к ыностранным делам посылаютца, на такие уборы ис казны его величества даетца». В конце концов П. П. Шафиров сознался, что «брал по слабости своей от Протопопова из государевых денег, винен и будет просить помилования» [Там же. Л. 281] $]^{29}$.

П.П. Шафиров признал свою вину в нецелевой трате государевых денег и покаялся, но речь шла о сравнительно небольшой сумме. Вышний суд обвинил вице-канцлера в казнокрадстве, буйном поведении в Сенате и приговорил к смертной казни с лишением всех чинов, титулов и имений ${ }^{30} .15$ февраля 1723 г. в день казни смертный приговор Шафирову Петр I заменил ссылкой в Якутск (затем в Ярославль). Однако уже 26 февраля император из Гродно отправил А. В. Макарову новый указ: «Приказывал я тебе, чтоб Шафирова послать в Ярославль, но понеже по письмам чаю быть розыску скорому, того ради лутче в Новгород его привесть для близости» [Архив СПбИИ РАН. Колл. 270. Оп. 1. Д. 103. Л. 299; Судное дело, с. 50].

Итак, во время заграничного путешествия царя 1716-1717 гг. П.П. Шафиров получил новую возможность показать себя умелым дипломатом, ведущим переговоры на высоком уровне. При его активном участии были подписаны два международных договора. Гораздо менее успешно вице-канцлер организовал прием на русскую

${ }^{27}$ Шез-де-пост - легкий кабриолет.

${ }^{28}$ Вечером 10 мая 1717 г. отель Ледигьер, где остановился Петр I, посетил семилетний Людовик XV вместе со своей свитой. На следующий день царь нанес ответный визит французскому королю в Тюильри [Мезин, с. 65].

29 Также П.П. Шафиров признался, что он вынул из почтовой сумки расписки Ивана Лаврецкого о выдаче ему казенных денег, которые потом сжег. Вице-канцлер сказал следователям: «А зжег-де он те росписки для того, чтоб по напрасному на него Протопопова поклепу в пороке не быть» [РГАДА. Ф. 248. Кн. 300. Л. 280 об.].

${ }^{30}$ Подробнее см: [Судное дело]. 
службу голландских матросов. Если первое заграничное путешествие П. П. Шафирова по Западной Европе привело к началу его блестящей карьеры, то после второго она начала клониться к закату.

\section{Список литературы}

Архив СПбИИ РАН. Ком. 270. Оп. 1. Д. 81, 84, 85, 103.

Бантыш-Каменский Н. Н. Обзор внешних сношений России (по 1800 год) : в 4 ч. М. : Тип. Э. Лисснера и Ю. Романа, Ч. 1. 1894. 304 с. Ч. 3. 1897. 320 с.

Бобылев В. С. Внешняя политика России эпохи Петра I. М. : Рос. ун-т дружбы народов, 1990. $168 \mathrm{c}$.

Вагеманс Э. Царь в республике : Второе путешествие Петра Великого в Нидерланды (1716-1717). СПб. : Европ. дом, 2013. 256 с.

Геи П. П. Карл Леопольд, дед императора Иоанна Антоновича : Рассказ барона Эйхгольца (1678-1747) // Русская старина. 1875. Т. 12. № 1. С. 1-26.

Гистория Свейской войны : (Поденная записка Петра Великого) : в 2 вып. / сост. Т. С. Майкова. М. : Кругъ, 2004. Вып. 1. 631 с.

Документы, относящиеся до пребывания царя Петра I во Франции за апрель и май месяцы 1717 г. // Сборник Императорского русского исторического общества. СПб. : Тип. Императ. акад. наук, 1881. Т. 34. С. 123-398.

Мартенс $\Phi . \Phi$. Собрание трактатов и конвенций, заключенных Россией с иностранными державами : в 15 т. СПб. : Тип. М-ва путей сообщения, 1880. Т. 5. Трактаты с Германией. 1656-1762. 408 с.

Материалы для истории русского флота : в 17 ч. СПб. : Тип. Морского м-ва, 1866. Ч. 3.726 c. Ч. 4.740 c.

Мезин С. А. Петр I во Франции. СПб. : Европ. дом, 2015. 312 с.

Молчанов Н. Н. Дипломатия Петра Великого. 3-е изд. М. : Междунар. отношения, 1990. $448 \mathrm{c}$.

Осмнадцатый век : Исторический сборник : в 4 кн. / изд. П. Бартеневым. М. : Тип. Т. Рис, у Мясницких ворот, Д. Воейкова, 1869. Кн. 4.536 с.

Походная канцелярия вице-канцлера Петра Павловича Шафирова : в 3 ч. / подг. Т. А. Базарова, Ю. Б. Фомина ; сост., вступ. ст., коммент. Т. А. Базаровой. СПб. : Міръ, 2011. Ч. 3. 1715-1723. $415 \mathrm{c}$.

Походный журнал 1716 года. СПб. : [Б. и.], 1855. 110 с.

РГАВМФ. Ф. 233. Оп. 1. Д. 113, 126, 129, 143.

РГАДА. Ф. 9. Оп. 5. Д. 1; Ф. 50. ОП. 1. 1717 г. Д. 23; Ф. 160. Оп. 1.1716 г. Д. 5; 1717 г. Д. 14; Ф. 198. Оп. 1. Д. 1035; Ф. 248. Кн. 300.

Редин Д., Серов Д. Второе путешествие Петра Первого в Европу в письмах барона П. П. Шафирова князю А. Д. Меншикову (1716-1717) // Quaestio Rossica. 2017. Т. 5. № 2. С. 471-502.

Рескрипты и указы императора Петра I к лифляндским генерал-губернаторам за 1717-1724 гг. // Сборник материалов и статей по истории Прибалтийского края : в 4 т. Рига : Тип. А. И. Липинского, 1880. Т. 3. С. 435-464.

Сборник выписок из архивных бумаг о Петре Великом : в 2 т. М. : Университет. тип., 1872. Т. 2. 408 с.

Серов Д. О. Администрация Петра I. 2-е изд., испр. и доп. М. : ОГИ, 2008. 291 с.

Серов Д. О. Судебная реформа Петра I : Историко-правовое исследование. М. : Зерцало-М, 2009. 488 с.

Стерликова A. A. Позовите Герца, старенького Герца... : Петр и «яковитская интрига» // Родина. 2007. № 11. С. 66-69.

Судное дело над действительным тайным советником бароном Шафировым и обер-прокурором Сената Скорняковым-Писаревым / публ. П. И. Иванова // Журнал М-ва юстиции. 1859. Т. 1. Кн. 3. С. 3-62. 
Фейгина С. А. Аландский конгресс : Внешняя политика России в конце Северной войны. М. : Изд-во АН СССР, 1959. 548 с.

\section{References}

Arkhiv SPbII RAN [The Archive of the Russian Academy of Sciences of the St Petersburg Institute of History]. Stock 270. List 1. Dos. 81, 84, 85, 103.

Bantysh-Kamenskii, N. N. (1894). Obzor vneshnikh snoshenii Rossii (po 1800 god) $v 4 \mathrm{ch}$. [A Review of the External Relations of Russia (until 1800). 4 Parts]. Moscow, Tipografiya E. Lissnera and Yu. Romana. Part 1. 304 p.

Bantysh-Kamenskii, N. N. (1894). Obzor vneshnikh snoshenii Rossii (po 1800 god) v 4 ch. [A Review of the External Relations of Russia (until 1800). 4 Parts]. Moscow, Tipografiya E. Lissnera and Yu. Romana. Part 3.320 p.

Bartenev, P. (Publ.) (1869). Osmnadtsatyi vek. Istoricheskii sbornik v $4 \mathrm{kn}$. [The $18^{\text {th }}$ Century. A Historical Anthology. 4 Books]. Moscow, Tipografiya T. Ris, u Myasnitskikh vorot, D. Voeikova. Book 4. 536 p.

Bobylev, V. S. (1990). Vneshnyaya politika Rossii epokhi Petra I [Russia's Foreign Policy under Peter I]. Moscow, Rossiiskii universitet druzhby narodov. $168 \mathrm{p}$.

Dokumenty, otnosyashchiesya do prebyvaniya tsarya Petra I vo Frantsii za aprel' i mai mesyatsy 1717 g. [Documents Related to the Stay of Tsar Peter I in France in April and May 1717]. (1881). In Sbornik Imperatorskogo russkogo istoricheskogo obshchestva. Vol. 34. St Petersburg, Tipografiya Imperatorskoy Akademii nauk, pp. 123-398

Feigina, S. A. (1959). Alandskii kongress. Vneshnyaya politika Rossii v kontse Severnoi voiny [The Alland Congress. Russia's Foreign Policy at the End of the Northern War]. Moscow, Izdatel'stvo Akademii nauk SSSR. 548 p.

Gets, P. P. (1875). Karl Leopol'd, ded imperatora Ioanna Antonovicha. Rasskaz barona Eikhgol'tsa (1678-1747) [Karl Leopold, Grandfather of Emperor Ioann Antonovich. The Story of Baron Eichholz (1678-1747)]. In Russkaya starina. Vol. 12. No. 1, pp. 1-26.

Ivanov, P. I. (Publ.). (1859). Sudnoe delo nad deistvitel'nym tainym sovetnikom baronom Shafirovym i ober-prokurorom Senata Skornyakovym-Pisarevym [The Case of Acting Privy Councilor Baron Shafirov and Attorney General of the Senate SkornaykovPisarev]. In Zhurnal Ministerstva yustitsii. Vol. 1. Book 3, pp. 3-62.

Maikova, T. S. (Comp.). (2004). Gistoriya Sveiskoi voiny (Podennaya zapiska Petra Velikogo) v 2 vyp. [The History of the Swedish War (Daily Notes of Peter the Great). 2 Issues]. Moscow, Krug". Iss. 1. 631 p.

Martens, F. F. (1880). Sobranie traktatov i konventsii, zaklyuchennykh Rossiei s inostrannymi derzhavami v $15 \mathrm{t}$. [A Collection of Treaties and Conventions Concluded by Russia with Foreign Powers. 15 Vols.]. St Petersburg, Tipografiya Ministerstva putei soobshcheniya. Vol. 5. Traktaty s Germaniei. 1656-1762. 408 p.

Materialy dlya istorii russkogo flota v $17 \mathrm{ch}$. [Materials for the History of the Russian Navy. 17 Parts]. (1866). St Petersburg, Tipografiya Morskogo ministerstva. Part 3. 726 p.

Materialy dlya istorii russkogo flota $v 17 \mathrm{ch}$. [Materials for the History of the Russian Navy. 17 Parts]. (1867). St Petersburg, Tipografiya Morskogo ministerstva. Part 4. 740 p.

Mezin, S. A. (2015). Petr I vo Frantsii [Peter I in France]. St Petersburg, Evropeiskii dom. 312 p.

Molchanov, N. N. (1990). Diplomatiya Petra Velikogo [Peter the Great's Diplomacy]. Ed. 3. Moscow, Mezhdunarodnye otnosheniya. 448 p.

Pokhodnaya kantselyariya vitse-kantslera Petra Pavlovicha Shafirova. [The Field Chancery of Vice-Chancellor Peter Pavlovich Shafirov. 3 Parts]. (2011). St Petersburg, Mir”. Part 3. 1715-1723. 415 p.

Pokhodnyi zhurnal 1716 goda [Route Journal of 1716]. (1855). St Petersburg, S. n. $110 \mathrm{p}$.

Redin, D., Serov, D. (2017). Vtoroe puteshestvie Petra Pervogo v Evropu v pis'makh barona P. P. Shafirova knyazyu A. D. Menshikovu (1716-1717) [Peter the Great's Second 
Voyage to Europe in the Letters of Baron P. P. Shafirov to Prince A. D. Menshikov (17161717)]. In Quaestio Rossica. Vol. 4. No. 2, pp. 471-502.

Reskripty i ukazy imperatora Petra I k liflyandskim general-gubernatoram. [Rescript and Edicts of Emperor Peter I to Livonia Governors-General]. (1880). In Sbornik materialov i statei po istorii Pribaltiiskogo kraya v 4 t. Riga, Tipografiya A. I. Lipinskogo. Vol. 3, pp. 435-464.

RGADA [Russian State Archive of Ancient Acts]. Stock 9. List 5. Dos. 1; Stock 50. List 1. Dos. 23 (1717); Stock 160. List 1. Dos. 5 (1716), Dos. 14 (1717); Stock 198. List 1. Dos. 1035; Stock 248. Book 300. 143.

RGAVMF [Russian State Archive of the Navy]. Stock 233. List. 1. Dos. 113, 126, 129,

Sbornik vypisok iz arkhivnykh bumag o Petre Velikom $v 2 t$. [A Collection of Excerpts of Archival Documents on Peter the Great. 2 Vols.]. (1872). Vol. 2. Moscow, Universitetskaya tipografiya. $408 \mathrm{p}$.

Serov, D. O. (2008). Administratsiya Petra I [Peter I's Administration]. Ed. 2, corr. and add. Moscow, OGI. 291 p.

Serov, D. O. (2009). Sudebnaya reforma Petra I. Istoriko-pravovoe issledovanie [The Judicial Reform of Peter I: A Historical and Legal Study]. Moscow, Zertsalo-M. 488 p.

Sterlikova, A. A. (2007). Pozovite Gertsa, staren'kogo Gertsa... Petr i “yakovitskaya intriga" [Call Hertz, Old Hertz... Peter and the 'Jacobite Intrigue']. In Rodina. No. 11, pp. 66-69.

Waegemans, E. (2013). Tsar'v respublike. Vtoroe puteshestvie Petra Velikogo $v$ Niderlandy (1716-1717) [A Tsar in a Republic. Peter the Great's Second Trip to the Netherlands (1716-1717)]. St Petersburg, Evropeiskii Dom. 256 p.

The article was submitted on 15.06.2017 